\title{
Mortalidade relacionada às doenças tropicais negligenciadas no Brasil, 2000-2011: magnitude, padrões espaço-temporais e fatores associados
}

\section{Mortality related to neglected tropical diseases in Brazil, 2000-2011: magnitude, spatiotemporal patterns and associated factors}

\author{
Francisco Rogerlândio Martins-Melo ${ }^{1,2}$. Alberto Novaes Ramos Júnior ${ }^{1,3}$. Jorg Heukelbach ${ }^{1,4}$. \\ 1 Departamento de Saúde Comunitária, Faculdade de Medicina, Universidade Federal do Ceará (UFC), Fortaleza, Ceará, Brasil. 2 \\ Doutorado em Saúde Coletiva pela Universidade Federal do Ceará (UFC), Mestrado em Saúde Pública pela Universidade Federal \\ do Ceará (UFC). Instituto Federal de Educação, Ciência e Tecnologia do Ceará (IFCE), Caucaia, Ceará, Brasil. 3 Doutorado em \\ Ciências Médicas, Universidade Federal do Ceará (UFC), Mestrado em Saúde Coletiva, Universidade Federal do Rio de Janeiro \\ (UFRJ), Rio de Janeiro, Rio de Janeiro, Brasil. 4 Anton Breinl Centre for Public Health and College of Public Health, Medical and \\ Veterinary Sciences, Division of Tropical Health and Medicine, James Cook University, Townsville, Australia.
}

\section{RESUMO}

Introdução: O Brasil é responsável pela maior parte da carga de doença relacionada às Doenças Tropicais Negligenciadas (DTNs) na América Latina. Objetivo: Descrever as tendências temporais, padrões espaço-temporais e fatores associados à mortalidade relacionada às DTNs no Brasil. Material e Métodos: Foi realizada uma série de estudos ecológicos baseados em dados secundários de mortalidade provenientes do Sistema de Informações sobre Mortalidade. Foram incluídos todos os óbitos relacionados às DTNs registrados no Brasil no período de 2000 a 2011 . A tese foi organizada em sete eixos temáticos de acordo com suas especificidades metodológicas e doenças analisadas: tendências temporais e padrões espaço-temporais da mortalidade relacionada ao grupo de DTNs (Eixo 1) e DTNs específicas com elevado impacto de mortalidade no Brasil (esquistossomose, hanseníase, neurocisticercose, leishmaniose visceral e coinfecção leishmaniose visceral e HIV/aids) (Eixos 2 a 6); análise dos fatores socioeconômicos, demográficos, ambientais/climáticos e de assistência à saúde associados à mortalidade relacionada às DTNs em nível municipal no Brasil, utilizando modelos de regressão linear multivariada e regressão espacial local (Eixo 7). Resultados: No período de estudo, 12.491 .280 óbitos foram registrados no Brasil. Foram identificadas 100.814 (0,81\%) declarações de óbitos em que pelo menos uma causa de morte relacionada às DTNs foi mencionada. A doença de Chagas foi a DTN mais mencionada $(72.827 ; 72,0 \%)$, seguido pela esquistossomose $(8.756 ; 8,7 \%)$ e hanseníase $(7.732 ; 7,6 \%)$. O coeficiente médio padronizado de mortalidade foi de 5,67 óbitos/100.000 habitantes (intervalo de confiança de 95\% [IC 95\%]: 5,56-5,77). Os maiores coeficientes de mortalidade foram observados em pessoas do sexo masculino, com $\geq 70$ anos de idade, raça/cor preta e residente na região Centro-Oeste. Os coeficientes de mortalidade apresentaram tendência de declínio significativo em nível nacional no período (variação percentual anual $[A P C]$ : -2,1\%; IC 95\%: -2,8; -1,3), com diminuição da mortalidade nas regiões Sudeste, Sul e Centro-Oeste, aumento na região Norte e estabilidade na região Nordeste. Foram identificados clusters de alto risco em todas as regiões brasileiras, destacando-se um cluster que abrange uma ampla área geográfica na região central do Brasil. A análise de regressão linear multivariada mostrou uma associação global positiva entre a mortalidade relacionada às DTNs e a taxa de urbanização, migração, índice de Gini, taxa de desemprego, saneamento inadequado, população de raça/cor preta, cobertura do Programa Bolsa Família e temperatura, enquanto houve uma relação negativa com a renda domiciliar, densidade de médicos, extrema pobreza, densidade domiciliar, umidade e precipitação. Os resultados da Regressão Geograficamente Ponderada (GWR) indicaram variações espaciais significativas em todas as associações entre as variáveis explicativas e a mortalidade por DTNs ao longo de todo o país, em que cada fator ecológico teve efeito diferente sobre a mortalidade em diferentes regiões brasileiras. Conclusões: As DTNs continuam sendo importantes causas de morte preveníveis e um problema de saúde pública no Brasil. A sobreposição geográfica e as áreas de alto risco para óbitos relacionados às DTNs chamam atenção para implementação de medidas integradas de controle nas áreas com maior morbidade e mortalidade. A distribuição espacial da mortalidade relacionada às DTNs nos municípios brasileiros está correlacionada com indicadores socioeconômicos, demográficos e ambientais/climáticos, com variações geográficas significativas. Estratégias locais abrangentes e medidas de prevenção e controle para DTNs devem ser formuladas de acordo com essas características nas regiões endêmicas brasileiras.

Palavras-chave: Doenças negligenciadas. Mortalidade. Epidemiologia. Análise espacial. Estudos de séries temporais. Determinantes sociais da saúde. Brasil. 


\section{ABSTRACT}

Introduction: Brazil accounts for most of the disease burden related to Neglected Tropical Diseases (NTDs) in Latin America. Objective: We analyzed temporal trends, spatiotemporal patterns and associated factors to NTD-related mortality in Brazil. Material and Methods: We performed a series of ecological studies based on secondary mortality data from the Mortality Information System. We included all NTD-related deaths recorded in Brazil from 2000 to 2011. The thesis is organized into seven Thematic Axes according to their methodological characteristics and diseases analyzed: Time trends and spatiotemporal patterns of mortality related to all NTDs (Axis 1) and specific NTDs with high mortality impact in Brazil (schistosomiasis, leprosy, neurocysticercosis, visceral leishmaniasis, and visceral leishmaniasis and HIV/AIDS co-infection) (Axes 2 to 6); analysis of socioeconomic, demographic, environmental and health care factors associated with NTD-related mortality at municipal level in Brazil, using multivariate linear regression and local spatial regression models (Axis 7). Results: During the study period, $12,491,280$ deaths were recorded in Brazil. We identified 100,814 (0.81\%) death certificates in which at least one cause of death was related to NTDs. Chagas disease was the most commonly mentioned NTD $(72,827 ; 72.0 \%)$, followed by schistosomiasis $(8,756,8.7 \%)$ and leprosy $(7,732 ; 7.6 \%)$. The average annual age-adjusted mortality rate was 5.67 deaths/100.000 inhabitants (95\% confidence interval [95\% CI]: 5.56-5.77). The highest mortality rates were observed in males, age group $\geq 70$ years, black race/color and residents in the Central-West region. The mortality rates presented a significant decreasing trend at national level during the period (annual percentage change $[A P C]$ : $-2.1 \%$; 95\% CI: $-2.8 ;-1.3$ ), with decreasing mortality in the Southeast, South and Central-West regions, increase in the North region and stability in the Northeast region. We identified high-risk clusters in all Brazilian regions, with a major cluster covering a wide geographical area in central Brazil. The multivariate linear regression analysis indicated a global positive association between NTD-related mortality rates and urbanization, migration, Gini index, unemployment, inadequate sanitation, black population, Bolsa Família Program coverage and temperature, while there was a negative association with household income, physician density, extreme poverty, household density, humidity and precipitation. The results of the Geographically Weighted Regression $(G W R)$ models indicated significant spatial variations in all associations between the explanatory variables and NTD-related mortality throughout the country; each ecological factor had a different effect on mortality in the different regions. Conclusions: NTDs remain important causes of preventable death and a public health problem in Brazil. The geographical overlap and areas of high-risk for NTD-related deaths identified call attention to implementation of integrated measures of control in areas with higher morbidity and mortality. The spatial distribution of NTD-related mortality in Brazilian municipalities is correlated with socioeconomic, demographic and environmental/climate factors, with significant geographic variations. Comprehensive local strategies and control and prevention measures for NTDs should be planned according to these characteristics in Brazilian endemic regions.

Keywords: Neglected diseases. Mortality. Epidemiology. Spatial analysis. Time series studies. Social determinants of health. Brazil.

Autor correspondente: Francisco Rogerlândio Martins-Melo, Rua Engenheiro João Alfredo, s/n, Novo Pabussú, Caucaia, Ceará, Brasil. CEP: 61600-000. Telefone: +55 85 3287-1451/3287-1467. E-mail: rogerlandio@bol.com.br

Conflito de interesses: Não há qualquer conflito de interesses por parte de qualquer um dos autores. Recebido em: 22 Fev 2016; Revisado em: 24 Fev 2016; Aceito em: 24 Fev 2016.

\section{Como citar:}

Martins-Melo FR, Ramos AN Júnior, Heukelbach J. Mortalidade relacionada às doenças tropicais negligenciadas no Brasil, 2000-2011: magnitude, padrões espaço-temporais e fatores associados. Rev Med UFC. 2016 jan-jun;56(1):79-80. 